\section{Degradable Mulch as an Alternative to Polyethylene for Watermelon Production}

\author{
Yahia A. Othman ${ }^{1,2}$ and Daniel I. Leskovar ${ }^{1}$
}

AdDitional INDEX wORDs. Citrullus lanatus, microbial activity, oxodegradable, plastic deterioration, soil health, yield

Summary. Polyethylene mulch is widely used for vegetable production in the United States as a tool to conserve water, control weeds, and produce earlier and cleaner products (i.e., less attached soil). However, the increasing labor costs for mulch removal and disposal after harvest and soil environmental pollution are major concerns. The objective of this study was to assess fruit yield and quality, mulch deterioration, soil microbial activity, and nutrient changes in 'Stargazer' watermelon (Citrullus lanatus) grown with degradable plastic mulch. The deterioration rates of degradable mulch were $7 \%, 37 \%, 57 \%$, and $92 \%$ after 120 , 210,300 , and 365 days, respectively, of placing the mulch in the field. However, the extra difference in using degradable mulch was calculated as $\$ 58.6 /$ acre (polyethylene \$600.9/acre vs. degradable \$659.5/acre), including all costs associated with laying and disposing. One year after placing mulch in the field, the nitrate content and total and active fungi numerically increased $(P=0.08)$ in soils with the degradable mulch compared with polyethylene mulch. However, there were no statistical differences in soil phosphorus, potassium, organic carbon, and total and active bacteria. Extra-large fruit size yield (category $>\mathbf{2 4 . 0}$ lb) from the polyethylene mulch treatment was higher than that from degradable mulch, whereas the 18.0- to 24.0-1b category was lower than that with degradable mulch. However, total yield and total soluble solids from both mulches were statistically similar. Considering the complete deterioration (less waste), mulch removal cost (not required), microbial associations (higher fungi abundance and activity), and similar yield and fruit quality of degradable mulch compared with polyethylene, the implementation of degradable mulches in commercial watermelon field practices is promising.

$\mathrm{P}$ olyethylene mulch is widely used for intensive vegetable production worldwide as a tool to control weeds, conserve water, and produce earlier and cleaner products (i.e., less attached soil). Mulched land area has increased during the past two decades.

Received for publication 22 Nov. 2021. Accepted for publication 6 Jan. 2022

Published online 23 February 2022.

${ }^{1}$ Texas A\&M AgriLife Research and Extension Center, Texas A\&M University, Uvalde, TX 78801

${ }^{2}$ Department of Horticulture and Crop Science, University of Jordan, Amman, Jordan 11942

This material is based on work that was partially funded by the Specialty Crop Block Grant Program through the Texas Department of Agriculture. We thank EcoPoly Solutions Inc. for providing materials, and also the National Center for Appropriate Technology and staff Manuel Figueroa-Pagan, Juan Esquivel, and Audra Elrod for their support. Any findings, conclusions and recommendations expressed in this article are those of the authors and do not necessary reflect the view of the funding agencies.

D.I.L. is the corresponding author. E-mail: d-leskovar@ tamu.edu.

This is an open access article distributed under the CC BY-NC-ND license (https://creativecommons. org/licenses/by-nc-nd/4.0/).

https://doi.org/10.21273/HORTTECH04997-21
The mulching market (sold for crops) in the United States was estimated to be $\$ 0.69$ billion in 2020 , whereas the global market for mulch films is projected to reach $\$ 5.1$ billion by 2027 (ReportLinker, 2020). However, mulch removal and disposal labor after harvest as well as air and soil environmental pollution are major concerns. In China, polyethylene mulching increased corn (Zea mays) and wheat (Triticum aestivum) grain yield by
$20 \%$ to $35 \%$ because of its soil warming and moisture conservation effects (Liu et al., 2014). However, the use of 20 million hectares of mulch has resulted in 1.25 million megagrams of residual plastic film, resulting in detrimental effects on soil structure, water and nutrient transport, crop growth, and, consequently, sustainable agriculture (Liu et al., 2014). Polyethylene films are resistant to degradation because of their high molecular weight and hydrophobicity; therefore, they can possibly persist in landfills for hundreds of years (Giordano et al., 2020).

The removal of polyethylene mulch residue is a major agronomic, economic, and environmental concern; therefore, the opportunity for using biodegradable mulch (e.g., paper-based and starchpolyester) in agriculture production has become more viable. The primary requirements for mulch to be considered biodegradable in organic farming (National Organic Program) are that they are 1) completely manufactured from biobased materials by fulfilling biobased standardized tests such as the American Society for Testing and Materials D6866 and 2) at least 90\% biodegradable by soil microbes in the field within a 2-year interval (Miles et al., 2017; Tofanelli and Wortman, 2020). A large meta-analysis performed by Tofanelli and Wortman (2020) comparing the performance of polyethylene and biodegradable mulch films in annual crops showed a reduction of soil temperature when using biodegradable mulch instead of polyethylene mulch. However, crop yields were not different between both films. Another study involving field-grown tomato (Solanum lycopersicum) production systems has shown that the percentages of area

\begin{tabular}{llll}
\hline $\begin{array}{l}\text { Units } \\
\text { To convert U.S. to SI, } \\
\text { multiply by }\end{array}$ & U.S. unit & SI unit & $\begin{array}{l}\text { To convert SI to U.S., } \\
\text { multiply by }\end{array}$ \\
\hline 0.4047 & $\mathrm{acre}(\mathrm{s})$ & $\mathrm{ha}$ & 2.4711 \\
0.3048 & $\mathrm{ft}$ & $\mathrm{m}$ & 3.2808 \\
0.7532 & $\mathrm{ft} / \mathrm{acre}$ & $\mathrm{m} \cdot \mathrm{ha}^{-1}$ & 1.3277 \\
2.54 & inch $(\mathrm{es})$ & $\mathrm{cm}$ & 0.3937 \\
25.4 & inch $(\mathrm{es})$ & $\mathrm{mm}$ & 0.0394 \\
0.4536 & $\mathrm{lb}$ & $\mathrm{kg}$ & 2.2046 \\
1.1209 & $\mathrm{lb} / \mathrm{acre}$ & $\mathrm{kg} \cdot \mathrm{ha}^{-1}$ & 0.8922 \\
1 & micron $(\mathrm{s})$ & $\mu \mathrm{m}$ & 1 \\
25.4 & mil(s) & $\mu \mathrm{m}$ & 0.0394 \\
1 & $\mathrm{mmh} / \mathrm{cm}$ & $\mathrm{dS} \cdot \mathrm{m}^{-1}$ & 1 \\
1 & $\mathrm{ppm}$ & $\mathrm{mg} \cdot \mathrm{L}^{-1}$ & 1 \\
1 & $\mathrm{ppm}$ & $\mu \mathrm{g} \cdot \mathrm{g}^{-1}$ & 1 \\
0.9072 & ton $(\mathrm{s})$ & $\mathrm{Mg}$ & 1.1023 \\
$\left({ }^{\circ} \mathrm{F}-32\right) \div 1.8$ & ${ }^{\circ} \mathrm{F}$ & ${ }^{\circ} \mathrm{C}$ & $\left({ }^{\circ} \mathrm{C} \times 1.8\right)+32$
\end{tabular}


remaining for starch-based and cellulose paper mulch at three geographically distinct U.S. locations were $0 \%(100 \% \mathrm{deg}$ radation) for cellulose mulch and $2 \%$ to $49 \%$ (51\% to $98 \%$ degradation) for starch-based mulch after 12 months of burial (Li et al., 2014). Watermelon (Citrullus lanatus) and pumpkin (Cucurbita pepo) are heavy fruits that can rest directly on the biodegradable mulch for an extended period, possibly accelerating the degradation process (e.g., mulch split early in the season) and consequently affecting soil temperature (reduced), weed pressure (increased), fruit yield, and fruit marketability (because of mulch adhesion on fruit) (Ghimire et al., 2018; Zhang et al., 2020). Ghimire et al. (2018) assessed the performance of biodegradable black mulch in a pumpkin field. At a depth of 10 $\mathrm{cm}$, the average soil temperature was $1{ }^{\circ} \mathrm{C}$ lower for biodegradable mulch and bare soil compared with polyethylene. Pumpkin grown with black biodegradable mulch had similar fruit yield as compared with polyethylene; however, $3 \%$ to $59 \%$ of the pumpkin fruit had mulch adhesion (varied with location) at harvest, and its removal became more difficult as the fruit surface dried.

Biodegradable mulch is normally converted through microbial activity in the soil to carbon dioxide, water, and natural substances (Kasirajan and Ngouajio, 2012). In addition, biodegradable mulch components including polymers can degrade when exposed to bioactive environments such as soil and compost. However, the source of polymer and additives in the degradable mulch may limit its use in organic farming (Kasirajan and Ngouajio, 2012; Miles et al., 2017). Research has shown that biodegradable (white and black) extruded mulch made from cassava starch and polybutylene adipate- $c o$-terephthalate showed small cracks in the structure 5 weeks after being tested in a strawberry (Fragaria xananassa) field; 8 weeks later, the maximum tensile strength and elongation at break were reduced (Bilck et al., 2010). Interestingly, polyethylene and biodegradable films had similar strawberry fruit yield and fruit quality. The highest yield and fruit quality of strawberry were obtained with polyethylene and biodegradable films such as BioFlex 1130 (FKuR Kunststoff, Willich, Germany),
Bio M 17 F53 (Plastimer Industrial Corp., Manila, Philippines), and Bio M 4b F28 (Plastimer Industrial Corp.) (Giordano et al., 2020). For tomato grown under high tunnel systems, biodegradable mulch was comparable to polyethylene for weed control, yield, and fruit quality; therefore, it may increase the sustainability of this protected cultivation method (Cowan et al., 2014). Broadleaf weed species grown in biodegradable mulch embedded with the herbicide 2-methyl4-chlorophenoxyacetic acid were killed after a quantity of the herbicide was released from the biodegradable mulch even at the $1 \% 2$-methyl-4-chlorophenoxyacetic acid concentration (Khan et al., 2020).

The use of plastic-like/polymer type black biodegradable mulch is promising because of the yields and weed suppression ability comparable to those of polyethylene film (Kijchavengkul et al., 2008). Four years of continuous use of soil-biodegradable plastic mulch had overall positive effects on soil (aggregate stability and water infiltration rate) and groundwater quality (residual nitrate and nitrite) when compared with bare soil, but not on microbial respiration (Sintim et al., 2021). Several studies have compared degradable and polyethylene mulches in terms of weed competition and yield; however, the influence of degradable mulch on watermelon production systems is limited, specifically its impact on soil chemistry, as well as microbial activity and abundance. The objective of this study was to assess yield, fruit quality [total soluble solids (TSS)], mulch deterioration and cost estimate, soil microbial activity, and soil nutrient changes of watermelon grown in the field with degradable and polyethylene plastic mulches.

\section{Materials and methods}

Site DESCRIPTION. 'Stargazer' watermelon was grown at the Texas A\&M AgriLife Research and Extension Center at Uvalde (lat. $29^{\circ} 12^{\prime} 57.6^{\prime \prime} \mathrm{N}$, long. $99^{\circ} 45^{\prime} 21.6^{\prime \prime} \mathrm{W}$ ) during Spring 2014. The study was conducted at a clay soil site (hyperthermic Aridic Calciustolls of the Uvalde series). Average summer and fall temperatures were 28 and $15{ }^{\circ} \mathrm{C}$, respectively (Fig. 1). Total rainfall between Apr. 2014 and Mar. 2015 was 27 inches. Irrigation was established using a subsurface drip system placed in the middle of the bed at a depth of $15 \mathrm{~cm}$. The total irrigation was 10 inches delivered in 10 irrigation events. Nitrogen $(\mathrm{N})$, phosphorus $(\mathrm{P})$, and potassium $(\mathrm{K})$ fertilizers $(4 \mathrm{~N}-4.4 \mathrm{P}-$ $8.3 \mathrm{~K}, 0 \mathrm{~N}-26 \mathrm{P}-0 \mathrm{~K}$, and $32 \mathrm{~N}-0 \mathrm{P}-0 \mathrm{~K})$ were applied during the experiment at the rates of 63,45 , and $63 \mathrm{lb} / \mathrm{acre}$, respectively. Fertilizers were applied in four split doses according to the grower's recommendations in Texas. The first dose [P: $47 \%$ of total dose $(0 \mathrm{~N}-26 \mathrm{P}-$ $0 \mathrm{~K})$ ] was incorporated into the soil $3 \mathrm{~d}$ before the installation of the irrigation system and mulches, and the next three doses were applied through the irrigation system. The second dose [N: $20 \%$ of the total dose $(32 \mathrm{~N}-0 \mathrm{P}-0 \mathrm{~K})]$ was applied 2 weeks after transplanting. The third dose [N: $50 \%$, P: $26.5 \%$, K: $50 \%$ of the total dose $(4 \mathrm{~N}-4.4 \mathrm{P}-8.3 \mathrm{~K}$ and $32 \mathrm{~N}-0 \mathrm{P}-0 \mathrm{~K})]$ was applied 1 month after transplanting. The fourth dose [N: $30 \%, \mathrm{P}: 26.5 \%, \mathrm{~K}$ : $50 \%$ of the total dose $(4 \mathrm{~N}-4.4 \mathrm{P}-8.3 \mathrm{~K}$ and $32 \mathrm{~N}-0 \mathrm{P}-0 \mathrm{~K})]$ was applied before the harvest stage. Weeds between rows were removed manually, and no herbicides were applied. Esfenvalerate pesticide (Asana XL; DuPont, Wilmington, DE) at $0.04 \mathrm{lb} /$ acre a.i. was applied early in the growing season to control cucumber beetle (Diabrotica undecimpunctata) and cutworms (Agrotis sp., Euxoa sp., and Peridroma sp.).

Plant material and mulch treATMENT. 'Stargazer' watermelon seeds were sown in polystyrene trays (model TRI28A; Speedling, Ruskin, FL) with 128 cells/tray $\left(1.5^{-} \times 1.5-\times 2.5\right.$-inch cells). After seeding, transplant trays were placed inside a germination chamber for $4 \mathrm{~d}$ in darkness and set at $20^{\circ} \mathrm{C}$. Then, seedlings were grown in greenhouse conditions for 5 weeks; at that time, seedlings reached the four true leaf stage. Thereafter, they were established in the field in either degradable or polyethylene plastic mulch beds. The transplants were established in the field $\mathrm{l} \mathrm{d}$ after the laying the plastic mulches. Transplants were planted in separate blocks, each consisting of one bed using a single row with plots with a length of $12 \mathrm{~m}$ (4 sub-replicates; total block length of $48 \mathrm{~m}$ ), width of $1 \mathrm{~m}$, and height of $15 \mathrm{~cm}$; plants were spaced 90 $\mathrm{cm}$ apart in the row. There was a total of eight experimental units. Four rows (length, $48 \mathrm{~m}$ ) represented the polyethylene and four rows (four experimental units) represented the degradable mulch. Two types of plastic mulching (black), 


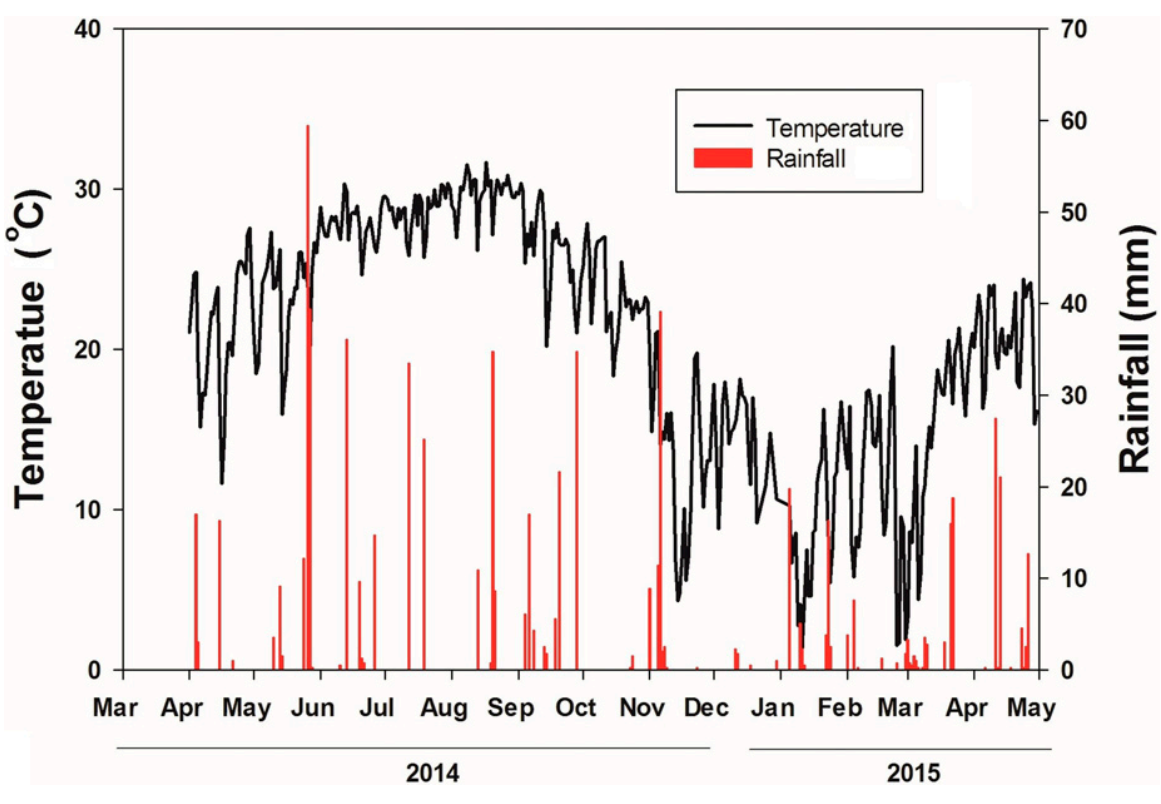

Fig. 1. Mean temperature and precipitation for watermelon field during the experimental period; $\left(1.8 \times{ }^{\circ} \mathrm{C}\right)+32={ }^{\circ} \mathrm{F}, 1 \mathrm{~mm}=0.0394$ inch.

degradable mulch (Exp. 4032; EcoPoly Solutions, Orillia, ON, Canada) and polyethylene (control), were used. During mulching application, the tension on the bed shaper/plastic layer was similar for both films, and no adjustment was required for the degradable mulch. The cultivation blocks treated with the two different films were randomized within each block. The degradable mulch material used was a linear low-density polyethylene film and a polymer with significant numbers of short branches, commonly made by copolymerization of ethylene with longer-chain olefins. It contains a high concentration of carbon black dispersed in thermoplastic resins, an ultraviolet stabilizer to maintain the integrity of the mulch, and an oxygen prodegradant material. The film contains a pro-oxidant additive (oxo-biodegradable blend) that accelerates the biodegradation process. The thicknesses of degradable and polyethylene mulches were 1.0 and 1.4 mil, respectively.

DETERIORATION VISUAL ASSESSMENT, YIELD, AND FRUIT QUALITY. After harvest, the films were not removed or tilled into the soil; they were left in the field for $360 \mathrm{~d}$ after laying for the evaluation of degradation. In addition, no herbicides were applied after harvesting to prevent weeds from breaking through. To illustrate the degradation, we cleaned a few meters from each plot at 180, 240, and 396 $\mathrm{d}$ after planting (DAP). Those sub- plots were not considered for further evaluations after weed removal. Mulch percent visual deterioration (PVD) was evaluated at $1,120,180,210,240$, 300,330 , and $360 \mathrm{~d}$ after mulch was placed in the field. During the deterioration evaluation, each experimental unit (replicate, $12 \mathrm{~m}$ long) for the four blocks was divided into 12 sub-blocks to reduce the assessment error; then, the total area covered by mulch was measured with a measuring tape to determine PVD. Mulch percent visual deterioration was estimated as the percent of soil exposed within the evaluated area such that $0 \%$ represented intact mulch and 100\% represented completely deteriorated mulch (Cowan et al., 2016). At the harvest stage (120-130 DAP), marketable yield (pounds per acre) and fruit quality (TSS) were determined during each harvest for a total of three harvests. Fruit TSS (four fruit per plot) was measured using a digital refractometer ( $\mathrm{Pal}-$ ette-PR32 $\alpha$; ATAGO U.S.A, Bellevue, WA). Marketable yield was graded as one of four categories based on the fruit weight ( $>24.0 \mathrm{lb}, 18.0$ to $24.0 \mathrm{lb}, 10.0$ to $18.0 \mathrm{lb}$, and $<10 \mathrm{lb}$ ).

SOIL BIOLOGICAL AND CHEMICAL ANALYsIS. Soil biological and chemical analyses were determined at the end of the study in Mar. 2015. Soil samples were taken from four replications per treatment from the top $20 \mathrm{~cm}$ from each of the degradable and polyethylene plots. Three soil cores per plot (replicate) were collected and mixed together, and two separate samples, one for biological and another for chemical analysis, were prepared. Soil nitrate $\left(\mathrm{NO}_{3}\right), \mathrm{P}$, and $\mathrm{K}$ were determined following the procedures of Mehlich (1978) and Al-Ajlouni et al. (2017). Soil samples from both treatments were oven-dried at $65^{\circ} \mathrm{C}$ for 16 h. Soil extracts ( $\mathrm{P}$ and $\mathrm{K}$ ) were prepared and elements were quantified by inductively coupled plasma mass spectrometry (ELAN ICP-MS; PerkinElmer, Waltham, MA). Nitrate-N was extracted from the soil using a l-N potassium chloride solution, and its content was measured using a spectrophotometer (Genesys 20; Thermo Fisher Scientific, Waltham, MA). Soil organic matter (percent) was determined by the combustion procedure (McGeehan and Naylor, 1988). For the soil biological analysis, core samples were collected from both mulch treatments, saved wet in zipper-locked bags inside an ice box, and shipped within $24 \mathrm{~h}$ to a soil testing laboratory (Earthfort, Corvallis, OR) for microbial assessment. Active bacteria and fungi were determined using the procedure of Ingham and Klein (1984); soil samples were stained with fluorescein diacetate and active bacteria and fungi were quantified using direct microscopy (COll; Olympus Corp., Hamburg, Germany), a dissecting scope for extraction, and a fluorescence microscope (DMLB; Leica Microsystems, Wetzlar, Germany) for genus identification. Total bacteria was determined using the fluorescein isothiocyanate method (Babiuk and Paul, 1970) and total fungi was determined using the procedure of Van Veen and Paul (1979). Soil extract plates were stained using fluorescein isothiocyanate, and the total number of bacteria was determined using a microscope. Total soil fungi hyphae was calculated by measuring the length and width of fungi and then converted to biomass using a microscope.

Mulch cost estimate. After harvest, the films were not removed or tilled into the soil; they remained in the field for $360 \mathrm{~d}$ after laying for the evaluation of degradation. The cost estimate was calculated following the procedure of Chen et al. (2018). The cost estimate included the mulch installation (machinery, mulch cost, and installation labor) and end-of-season inputs (mulch removal labor, 
mulch disposal, and machinery for plowing the remaining mulch fragments into the soil). Mulch cost was calculated as the total number of rolls required to cover 1 acre (the thickness of the mulch was neglected). The width of the roll of both polyethylene mulch and degradable mulch was $1.5 \mathrm{~m}$. The mulch installation (same for polyethylene degradable mulches) was the sum of the machinery and labor costs. The machinery cost (per acre) refers to the value of using the tractor for mulch installation by considering the purchase cost of the machine and salvage value (cost at the end of its useful life). Installation labor cost is the labor per diem rate per hour multiplied by the total hours required to cover 1 acre with mulch. The mulch removal (machinery and labor) cost is the total cost of the machinery removal (similar to mulch installation) plus the cost of manual removal of plants and clearing the plastic remnants. The wage rate was estimated as $\$ 15$ per hour for the installation and the removal of plants and polyethylene plastic.

Statistical anAlysis. A randomized complete block design with four replications was used. Mulch coverage percentage, marketable yield, fruit quality, soil chemical properties, and microbial data were analyzed using Student's $t$ test at $P \leq 0.05$ (SAS ver. 9.4 for Windows; SAS Institute, Cary, NC).

\section{Results and discussion}

Mulch Deterioration. Polyethylene mulch has been widely used in vegetable crop production to reduce weed competition, reduce water losses, and, consequently, increase yield. To our knowledge, there have been few experimental field studies using biodegradable mulch films for melon ( $\mathrm{Cucu}$ mis melo) cultivation. López et al. (2007) found that the use of biodegradable materials produced similar 'Nicolas Fl' melon yields (compared with polyethylene), that the film materials had disappeared 5 to 6 months after being placed in the field, and that polyethylene remained in the ground. However, Helios and Tendral melon cultivars grown in polyethylene mulch had higher early and total marketable yields compared with those grown in biodegradable mulch (Vetrano et al., 2009).
The nondegradable characteristics of the plastic film (polyethylene) cause serious environmental pollution when not adequately removed and recycled (Da Silva, 2020). Conversely, Kijchavengkul et al. (2008) found that black biodegradable films started to degrade $(\approx 10 \%)$ in the field after $\approx 8$ weeks (56śd). A meta-analysis of 66 studies of the performance of polyethylene and biodegradable (mainly paper-based and starch-polyester) mulch films in annual field crops revealed that biodegradable mulch reduced soil temperature by $4.5 \%$ compared with polyethylene (Tofanelli and Wortman, 2020). However, crop yields were not different between both films. In this study, the deterioration rates of degradable mulches were $7 \%$, $20 \%, 37 \%, 44 \%, 57 \%, 83 \%$, and $92 \%$ after $120,180,210,240,300,330$, and $365 \mathrm{~d}$ after field transplanting, respectively (Figs. 2 and 3). However, no deterioration was noticed in the polyethylene mulch during the study period. A previous study of field and high-tunnel cucumber has shown that biodegradable mulch increased soil temperature by $2{ }^{\circ} \mathrm{C}$ and soil moisture by $8 \%$, and were effective for suppressing weed emergence at the early growth stage when compared with bare soil (Wortman et al., 2016). In that study, the bioplastic film started to deteriorate $34 \mathrm{~d}$ after placement $(3 \%)$ in the field, and overall deterioration occurred after 11 months.

The degradation rate of biodegradable mulches depends mostly on the soil type where the biodegradable mulch is applied, as well as soil moisture content, wind, and temperature (Borrowman et al., 2020; Serrano-Ruiz et al., 2021). Plant surface (phylloplane) fungi strains can grow underneath the biodegradable mulch and form breaks along the direction of hyphal growth, indicating that the fungi release bioplastic-degrading enzymes that directly contribute to the acceleration of the degradation process (Koitabashi et al., 2012). Another study has reported that phylloplane fungi isolated from wheat, barley (Hordeum vulgare), and rice (Oryza sativa) plants increase the degradation process of biodegradable plastic mulch films in soil environments (Koitabashi et al., 2012). In this study, the slow deterioration at the first 4 months (7\%) could be partially explained by the full coverage of this vine crop canopy from above, which reduced the exposure of the mulch to direct sunlight, thus leading to a slower deterioration process (Fig. 2). After watermelon fruit harvest ends, leaf senescence rapidly accelerates, followed by complete plant decay, leading to a higher mulch exposure area and, consequently, faster deterioration.

Unlike the biodegradable mulch, which is tilled into the soil at the end of the growing season to complete degradation, polyethylene needs to be physically removed, thus adding additional labor costs (Bandopadhyay et al., 2018; Wortman et al., 2016). Figure 4 shows the

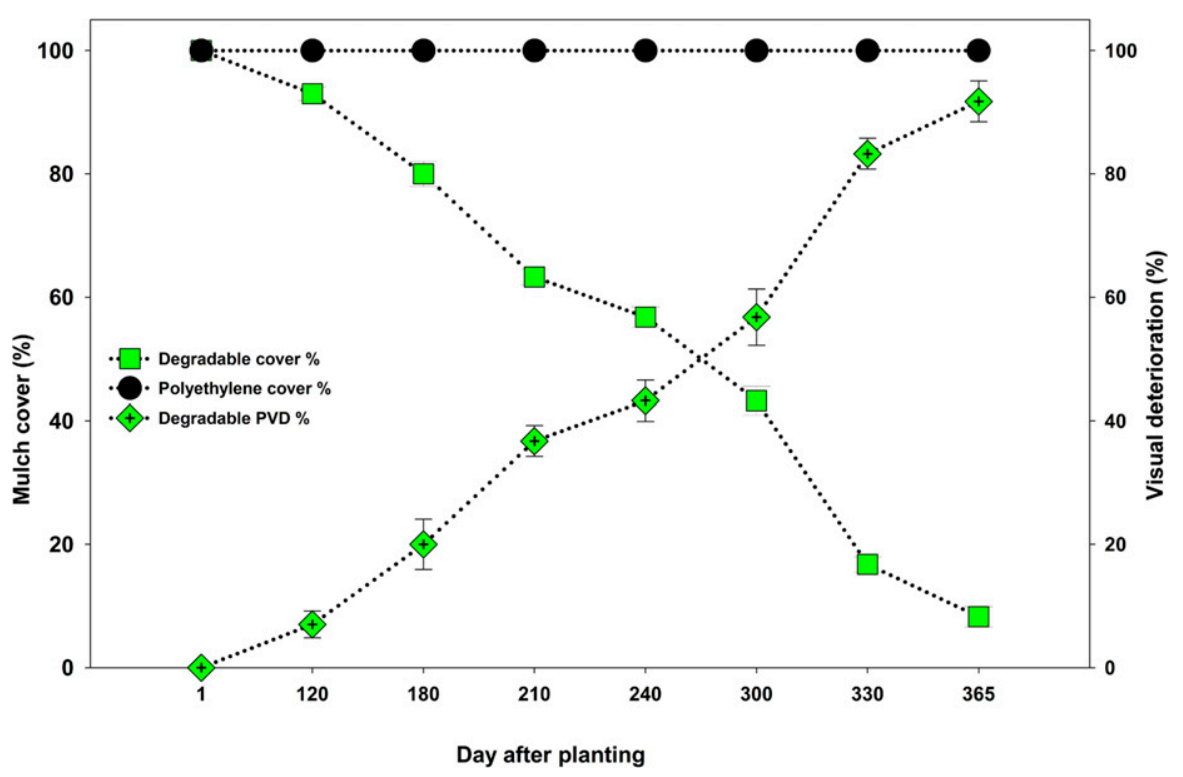

Fig. 2. Degradable and polyethylene plastic mulches cover and percent visual deterioration (PVD) for watermelon field across the study period. 


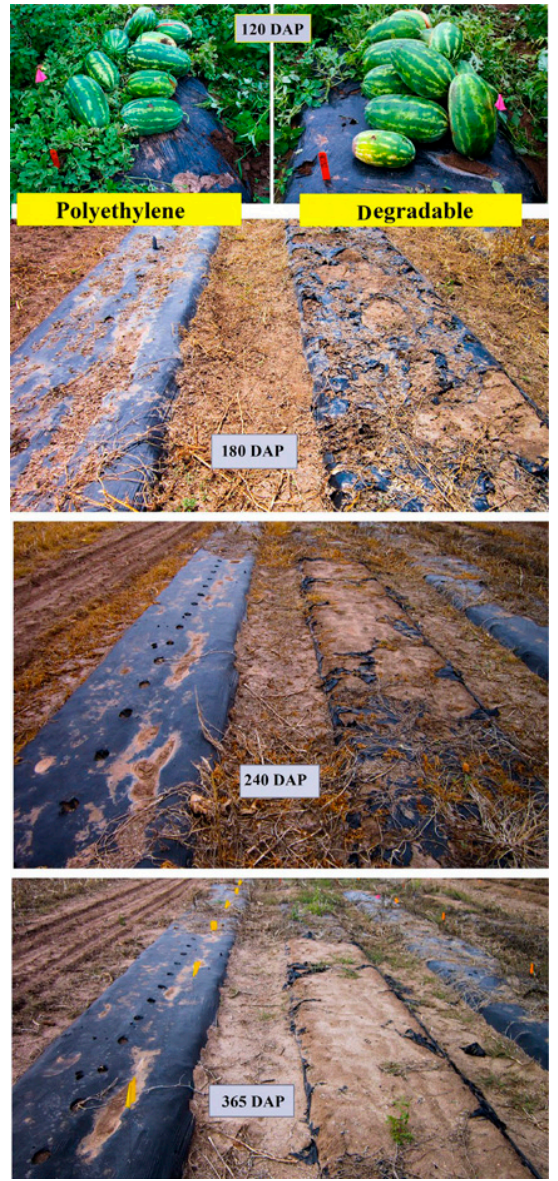

Fig. 3. Polyethylene and degradable plastic mulches cover after 120, 180, 260 , and $365 \mathrm{~d}$ after planting (DAP) for watermelon field.

degradable mulch residue after 1 year of placement in the field. We found that the mulch that was exposed to direct sunlight was totally deteriorated, whereas the buried sides of the degradable did not fully decompose $(\approx 8 \%)$. This result highlights the roles of temperature conditions and light intensity in the deterioration process. The natural tendency of biodegradable mulches to photodegrade involves the gradual reaction of the backbone polymer with atmospheric oxygen in the presence of light, which in turn induces the film brittleness and susceptibility to fragmentation (Ammala et al., 2011). However, when the biodegradable mulch is buried, low temperatures and oxygen availability (compared with air) slow the biodegradation process (Serrano-Ruiz et al., 2021).

After l year of mulch placement, the deterioration of the degradable mulch was $92 \%$, whereas that of polyethylene was $0 \%$. During the growing season and senescence stage, the mulch was

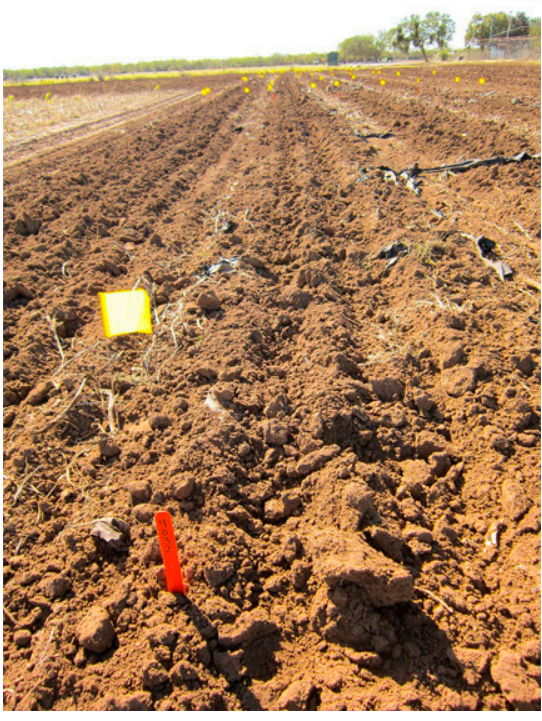

Fig. 4. Degradable plastic mulches cover residue after tillage and incorporation with soil. Tillage was performed $365 \mathrm{~d}$ after placing the degradable mulch in the watermelon field.

held by plants; therefore, we believe that reduction of the mulch cover $(\approx 40 \%)$ can be attributed to the biodegradation process. However, at the end of the growing season, after plant death, the mulch was exposed to wind. At that time, part of the mulch was biodegraded into the soil, and the remaining microplastic fragments of the degraded mulch were blown away by the wind (visual observation).

Mulching represents a significant input cost for watermelon growers, especially the material cost. In this study, the estimated total cost for degradable mulch was $\$ 659.5 /$ acre, whereas that for polyethylene was $\$ 600.9$ /acre (Table 1). Polyethylene mulch removal is a significant added labor cost (\$283.3/acre). However, degradable mulch requires an additional input cost to plow mulch into the soil $(\$ 113.3 /$ acre $)$. In addition, mulch material for degradable mulch was $171 \%$ higher than polyethylene. Overall, the extra difference in using degradable mulch was calculated as $\$ 58.6 /$ acre.

SOIL CHEMICAL CONCENTRATION AND Microbial LEVELS. Soil P and K contents and organic matter (percent) showed no significant differences in mulching treatments (Table 2). However, the soil $\mathrm{NO}_{3}-\mathrm{N}$ concentration of degradable mulch was $38 \%$ higher $(P=0.08)$. Growing strawberry on BioFlex 1130 and Bio M 4b F28 biodegradable films, which completely degrade in soil and are compostable, resulted in higher fruit calcium and magnesium contents compared with polyethylene mulching (Giordano et al., 2020). Overall, the higher concentration of soil nutrients could be attributed to the compounds used in the formulation of the degradable materials.

The main environmental concerns when using polyethylene plastic are the mulch residue left in the soil and the inherent environmental and biological damage to the abundance and diversity of the soil microbial community. Therefore, biodegradable films are an alternative with beneficial soil microbial activity compared to polyethylene mulch (Bandopadhyay
Table 1. Cost estimate per acre (mulch installation and end-of-season inputs) for polyethylene and degradable mulch. The distance between watermelon bed centers was $1.8 \mathrm{~m}(5.91 \mathrm{ft})$, and the total length of mulch needed was $7342 \mathrm{ft} / \mathrm{acre}$ $\left(5529.8 \mathrm{~m} \cdot \mathrm{ha}^{-1}\right)$.

\begin{tabular}{lcc}
\hline & \multicolumn{2}{c}{ Estimate cost $(\$ / \text { acre })^{\mathbf{z}}$} \\
\cline { 2 - 3 } Costs & Polyethylene & Biodegradable \\
\hline Mulch installation & 80.9 & 80.9 \\
Machinery & 141.6 & 384.4 \\
Mulch cost & 80.9 & 80.9 \\
Installation labor & & \\
& & 0 \\
End of season & 283.3 & 0 \\
Mulch removal labor & 14.2 & 113.3 \\
Mulch disposal & 0 & 659.5 \\
Machinery for mulch plow into soil & 600.9 & $58.6+$ \\
Total input cost & & \\
Difference in using biodegradable mulch & &
\end{tabular}


Table 2. Soil chemical and microbial analysis of degradable and polyethylene (control) plastic mulches. Chemical and microbial analysis was conducted 1 year after planting watermelon.

\begin{tabular}{lccc}
\hline Analysis $^{\mathbf{z}}$ & Degradable & Polyethylene & $\boldsymbol{P v a l u e}^{\mathbf{y}}$ \\
\hline Soil chemical analysis & & & \\
$\mathrm{pH}$ & 7.9 & 7.8 & 0.83 \\
Electrical conductivity & 0.57 & 0.61 & 0.91 \\
(mmho/cm) & & & \\
Organic matter $(\%)$ & 3.23 & 3.11 & 0.49 \\
Phosphorus (ppm) & 73.8 & 73.6 & 0.96 \\
Potassium (ppm) & 864 & 892 & 0.31 \\
Nitrate nitrogen (ppm) & 62.0 & 45.0 & 0.08 \\
Soil microbial analysis & & & \\
Active bacterial (ppm) & 6.65 & 8.71 & 0.29 \\
Total bacterial (ppm) & 189 & 157 & 0.27 \\
Active fungal (ppm) & 2.24 & 1.10 & 0.07 \\
Total fungal (ppm) & 23.7 & 15.4 & 0.06 \\
Hyphal diameter (micron) & 2.84 & 2.71 & 0.72 \\
\hline
\end{tabular}

${ }^{\mathrm{z}} 1 \mathrm{mmho} / \mathrm{cm}=1 \mathrm{dS} \cdot \mathrm{m}^{-1}, 1 \mathrm{ppm}=1 \mathrm{mg} \cdot \mathrm{L}^{-1}, 1 \mathrm{ppm}=1 \mu \mathrm{g} \cdot \mathrm{g}^{-1}, 1 \mathrm{micron}=1 \mu \mathrm{m}$.

${ }^{y}$ All variables did not differ significantly at $P \leq 0.05$.

et al., 2018). In a 3-year study of a watermelon crop grown under conventional tillage (bare soil fully tilled, no plastic mulch) compared to strip tillage ( $80 \%$ cover crop residue, $20 \%$ tilled), Leskovar et al. (2016) found that the total bacteria and fungi from strip tillage plots was 6- to 8-fold higher than those under conventional tillage. The results from that study indicated that the living mulching left in the strip tillage system acted as a surface barrier that positively affected the soil microclimate. Similarly, plastic mulches were shown to alter soil microbial community composition and functioning via microclimate modification, increased soil temperature, moisture content, and reduce light transmissivity (Bandopadhyay et al., 2018). In this study, the total bacteria in the soil with degradable mulch was $20 \%$ higher numerically, but not statistically, whereas the total fungi was $54 \%$ higher $(P=0.06)$ than that in polyethylene. In addition, the fungi content in the degradable plots was $104 \%$ higher $(P=0.07)$ than that in polyethylene plastic mulch. Higher microbial activity could be partially attributed to the degradable mulch components, which act as a food source for soil biota. A previous study showed that after tillage practices that included the incorporation of biodegradable residue into the soil, mulch fragments can affect soil organic matter dynamics and, consequently, enhance microbial abundance (Bandopadhyay et al., 2018).

A healthy soil acts as a dynamic living system that delivers multiple ecosystem services, such as controlling soil nutrient recycling, mitigating negative greenhouse gases, and sustaining water quality and plant productivity (Tahat et al., 2020). Several investigations revealed a significant association between soil health and soil microorganism diversity and activity (Al-Karaki et al., 2007; Karlen et al., 2003; Othman and Leskovar, 2018, 2020; Tahat et al., 2020). A study that characterized the compounds released from different biodegradable mulches to water solutions before biodegradation revealed that several compounds used in the formulation of the materials were identified in the solution, including glycerol, 1,4-butanediol, terephthalic acid, mono-saccharides, di-saccharides, adipic acid, lactic acid, and fatty acids (Serrano-Ruíz et al., 2020). In addition, higher soil microbial biomass $\mathrm{C}$ and soil organic matter mineralization were related to improved (increased) temperature ranges under the biodegradable mulch as compared to polyethylene (Moreno and Moreno, 2008). A total soil fungi and bacteria numerical increase (not statistically significant) was observed in this study. This slight increase could correspond to an increase in the diversity in these organisms, although microbial biodiversity measurements were not part of this study. Considering findings from previous studies and our results, the use of degradable mulch has positive or similar non-negative impact on soil microbial, and those effects are likely associated with the compounds used in the formulation of the degradable mulch.
YIELD AND FRUIT QUALITY. The major concerns of farmers when adopting the use of degradable mulching are the decomposition time and the exposure area of the mulch, as well as weed control, soil moisture retention (reduced evaporative water losses), and yield. In this study, the degradable mulch started to decompose early; however, in general, it remained functional during use (only $7 \%$ deterioration until harvesting stage) and did not significantly affect total yield and fruit quality. Mean total yield and TSS of watermelon grown with degradable mulch were $33,024 \mathrm{lb} /$ acre and $10.6 \%$, whereas those of watermelon grown with polyethylene were 34,076 $\mathrm{lb} /$ acre and $10.5 \%(P>0.3$ for yield and TSS). A 2-year study of field-grown tomato similarly showed that yield and fruit quality (TSS, firmness, dry weight, juice content, and shape) with both polyethylene and biodegradable mulches were statistically similar (Moreno and Moreno, 2008). Although mulch adhesion to the fruit was not measured at harvest, we did not notice (visual inspections) any mulch fragments sticking to fruit, as found by Ghimire et al. (2018) on pumpkin.

With regard to harvested fruit grades, the extra-large fruit size $(>24$ lb) from polyethylene mulch was higher than that from degradable, whereas the fruit size category 18.0 to $24.0 \mathrm{lb}$ from degradable mulch was higher than that from polyethylene (Fig. 5). It appears that more watermelon fruit that were smaller in size were produced with the degradable film than with the conventional film. This size compensation shift produced similar total yields for both films.

Substitution of polyethylene with biodegradable films will depend on the costs of materials, labor, mulch removal, and local or regional environmental regulations. From an environmental point of view, biodegradable mulch is a viable and attractive alternative to polyethylene plastic; however, from an economic point of view, they have a higher price and comparable yields, as noted for tomato (Cirujeda et al., 2012) and strawberry (Costa et al., 2014). The estimated costs of biodegradable mulch per $1.5 \times 1000$-m roll are $\approx \$ 350 /$ roll for Mater-Bi (Novamont, Novara, Italy), \$235/roll for Sphere (Sphere Group Spain, Zaragoza, Spain), and $\approx \$ 280 /$ roll for Bioflex 1130 . Polyethylene mulch costs range from $\$ 50$ 


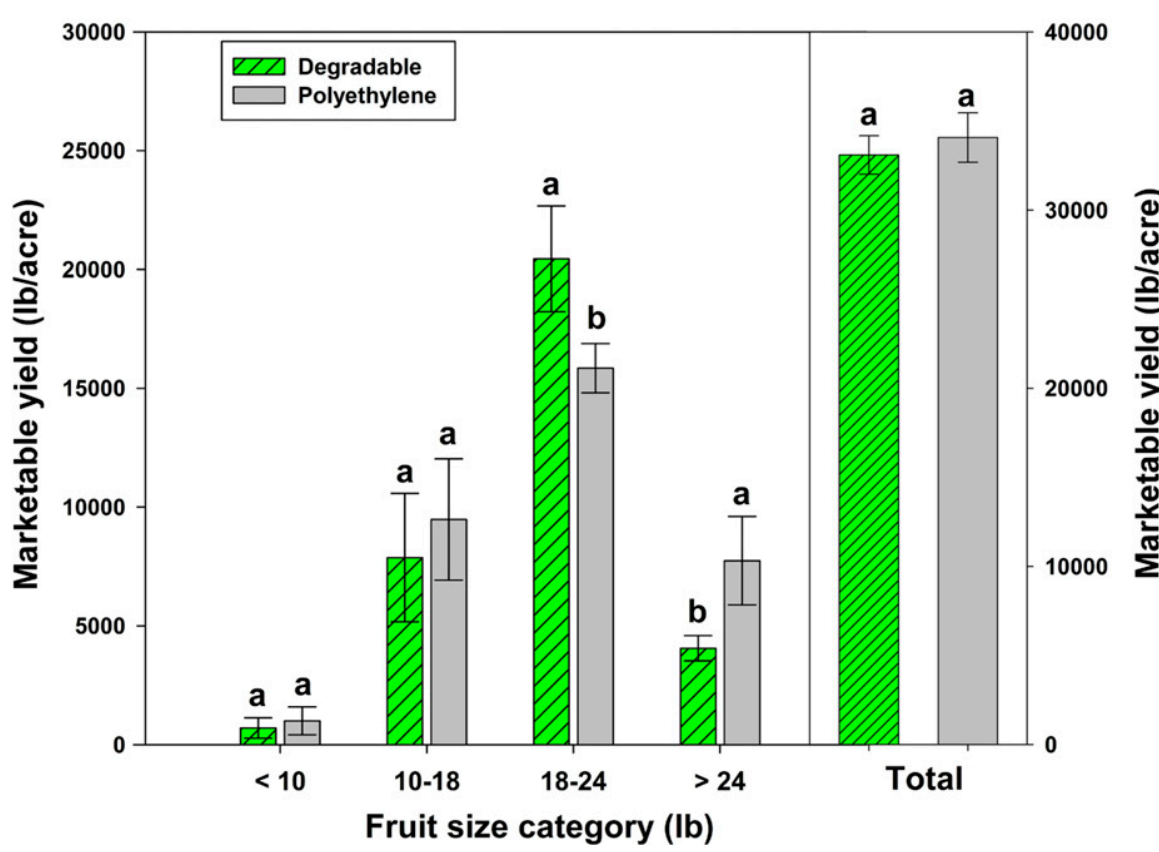

Fig. 5. Watermelon total marketable yield by fruit size category of degradable and polyethylene (control) plastic mulches. Different letters within fruit size categories are significantly different at $P \leq 0.05 ; 1 \mathrm{lb}=0.4536 \mathrm{~kg}, 1 \mathrm{lb} /$ acre $=1.1209$ $\mathrm{kg} \cdot \mathrm{ha}^{-1}$.

to $\$ 170$ per roll, depending on shipment distance and source. However, because of agricultural and environmental impacts, Liu et al. (2014) concluded that governments need to improve plastic film standards and quality control to enhance mulch recycling and encourage the research and development of biodegradable mulch to promote effective control to mitigate the residual mulch pollution effects. Considering the extra cost for removing polyethylene and the soil benefits of degradable mulches, the results of this study provide additional evidence to encourage growers to use degradable mulch films as an eco-sustainable agricultural practice for watermelon production.

\section{Conclusions}

This study evaluated the degradation and cost of plastic mulch and its impact on soil $\mathrm{NO}_{3}-\mathrm{N}$, microbial changes, yield, and quality of watermelon. Compared with polyethylene film, the degradable mulch almost completely degraded (92\%) l year after transplanting, and no mulch removal was required. Although the degradable mulch total cost was more than double that of the polyethylene mulch (\$384.4/acre vs. \$141.6/acre) and required $\$ 113.3 /$ acre extra for tilling the remaining $8 \%$ into the soil at the end of the growing season, the removal and disposal process of polyethylene added an additional labor cost estimated at $\$ 297.5 /$ acre . Overall, the additional cost of using degradable mulch was calculated as $\$ 58.6 /$ acre. The degradable mulch contributed to enriching the soil $\mathrm{NO}_{3}-\mathrm{N}$ concentration and total and active fungi as compared with soil under the conventional polyethylene plastic mulch. However, the total marketable yield and TSS were similar with both mulches. Overall, the future implementation of degradable mulches in vegetable production, including watermelon, appears promising. However, a long-term study (multiple growing seasons) and more replications are critical for a full assessment of soil health. In addition, detailed soil chemical and biological analyses are required to evaluate the long-term impact of degradable mulches on soil nutrients and microbial activity.

\section{Literature cited}

Al-Ajlouni, M., J. Ayad, and Y. Othman. 2017. Increasing nutrient levels promote growth and flower quality in lilies grown under soilless culture. Hort. Sci. (Prague) 44:171-177, https://doi.org/10.17221/ 166/2016-HORTSCI.

Al-Karaki, G., Y. Othman, and A. AlAjmi. 2007. Effects of mycorrhizal fungi inoculation on landscape turf establishment under Arabian Gulf region conditions. Arab Gulf J. Sci. Res. 25:147-152.

Ammala, A., S. Bateman, K. Dean, E. Petinakis, P. Sangwan, S. Wong, Q. Yuan, L. Yu, C. Patrick, and K. Leong. 2011. An overview of degradable and biodegradable polyolefins. Prog. Polym. Sci. 36:1015-1049, https://doi.org/10.1016/ j.progpolymsci.2010.12.002.

Babiuk, L.A. and E. Paul. 1970. The use of fluorescein isothiocyanate in the determination of the bacterial biomass of a grassland soil. Can. J. Microbiol. 16:57-62, https://doi.org/10.1139/m70-011.

Bandopadhyay, S., L. Martin-Closas, A. Pelacho, and J. DeBruyn. 2018. Biodegradable plastic mulch films: Impacts on soil microbial communities and ecosystem functions. Front. Microbiol. 9:819, https:// doi.org/10.3389/fmicb.2018.00819.

Bilck, A., M. Grossmann, and F. Yamashita. 2010. Biodegradable mulch films for strawberry production. Polym. Test. 29:471-476, https://doi.org/10.1016/j. polymertesting.2010.02.007.

Borrowman, C., P. Johnston, R. Adhikari, K. Saito, and A. Patti. 2020. Environmental degradation and efficacy of a sprayable, biodegradable polymeric mulch. Polym. Degrad. Stabil. 175:109126, https://doi. org/10.1016/j.polymdegradstab.2020. 109126.

Chen, K., S. Galinato, S. Ghimire, S. MacDonald, T. Marsh, C. Miles, P. Tozer, and M. Velandia. 2018. Performance and adoptability of biodegradable mulch. Report No. LCA/SC-2018-01. 2 Sept. 2021. <https://ag.tennessee.edu/ biodegradablemulch/Documents/ChenMulch-calculcator-introduction.pdf $>$.

Cirujeda, A., J. Aibar, A. Anzalone, L. Closas, R. Meco, M. Moreno, A. Pardo, A. Pelacho, F. Rojo, A. Royo-Esnal, M. Suso, and C. Zaragoza. 2012. Biodegradable mulch instead of polyethylene for weed control of processing tomato production. Agron. Sustain. Dev. 32:889-897, https://doi.org/10.1007/s13593-0120084-y.

Costa, R., A. Saraiva, L. Carvalho, and E. Duarte. 2014. The use of biodegradable mulch films on strawberry crop in Portugal. Scientia Hort. 173:65-70, https:// doi.org/10.1016/j.scienta.2014.04.020.

Cowan, J., C. Miles, P. Andrews, and D. Inglis. 2014. Biodegradable mulch performed comparably to polyethylene in high tunnel tomato (Solanum lycopersicum L.) production. J. Sci. Food Agr. 94:1854 1864, https://doi.org/10.1002/jsfa.6504.

Cowan, J., A. Saxton, H. Liu, K. Leonas, D. Inglis, and C. Miles. 2016. Visual 
assessments of biodegradable mulch deterioration are not indicative of mulch degradation. HortScience 51:245-254, https:// doi.org/10.21273/HORTSCI.51.3.245.

Da Silva, G. 2020. Biodegradable mulch of recycled paper reduces water consumption and crop coefficient of pak choi. Scientia Hort. 267:109315, https://doi. org/10.1016/j.scienta.2020.109315.

Ghimire, S., A. Wszelaki, J. Moore, D. Inglis, and C. Miles. 2018. The use of biodegradable mulches in pie pumpkin crop production in two diverse climates. HortScience 53:288-294, https://doi. org/10.21273/HORTSCI12630-17.

Giordano, M., C. Amoroso, C. ElNakhel, Y. Rouphael, S. De Pascale, and C. Cirillo. 2020. An appraisal of biodegradable mulch films with respect to strawberry crop performance and fruit quality. Horticulturae 6:48, https://doi. org/10.3390/horticulturae6030048.

Ingham, E. and D. Klein. 1984. Soil fungi: Relationships between hyphal activity and staining with fluorescein diacetate. Soil Biol. Biochem. 16:273-278, https://doi. org/10.1016/0038-0717(84)90014-2.

Karlen, D.L., C. Ditzler, and S. Andrews. 2003. Soil quality: Why and how? Geoderma 114:145-156, https://doi.org/ 10.1016/S0016-7061(03)00039-9.

Kasirajan, S. and M. Ngouajio. 2012. Polyethylene and biodegradable mulches for agricultural applications: A review. Agron. Sustain. Dev. 32:501-529, https://doi. org/10.1007/s13593-011-0068-3.

Khan, H., S. Kaur, T. Baldwin, I. Radecka, G. Jiang, I. Bretz, K. Duale, G. Adamus, and M. Kowalczuk. 2020. Effective control against broadleaf weed species provided by biodegradable PBAT/PLA mulch film embedded with the herbicide 2-methyl-4chlorophenoxyacetic acid (MCPA). ACS Sustain. Chem. \& Eng. 8:5360-5370, https:// doi.org/10.1021/acssuschemeng.0c00991.

Kijchavengkul, T., R. Auras, M. Rubino, M. Ngouajio, and R. Fernandez. 2008. Assessment of aliphatic-aromatic copolyester biodegradable mulch films. Part I: Field study. Chemosphere 71:942-953, https:// doi.org/10.1016/j.chemosphere.2007. 10.074 .

Koitabashi, M., M. Noguchi, Y. SameshimaYamashita, S. Hiradate, K. Suzuki, S. Yoshida, T. Watanabe, Y. Shinozaki, S. Tsushima, and H. Kitamoto. 2012. Degradation of biodegradable plastic mulch films in soil environment by phylloplane fungi isolated from gramineous plants. AMB Express 2:40, https://doi.org/ 10.1186/2191-0855-2-40.
Leskovar, D., Y. Othman, and X. Dong. 2016. Strip tillage improves soil biological activity, fruit yield and sugar content of triploid watermelon. Soil Tillage Res. 163:266-273, https://doi.org/10.1016/ j.still.2016.06.007.

Li, C., J. Moore-Kucera, C. Miles, K. Leonas, J. Lee, A. Corbin, and D. Inglis. 2014. Degradation of potentially biodegradable plastic mulch films at three diverse U.S. locations. Agroecol. Sustain. Food Syst. 38:861-889, https://doi.org/ 10.1080/21683565.2014.884515.

Liu, E., Q. He, and C. Yan. 2014. 'White revolution' to 'white pollution'- Agricultural plastic film mulch in China. Environ. Res. Lett. 9:091001, https://doi.org/ 10.1088/1748-9326/9/9/091001.

López, J., A. González, J. Fernández, and S. Bañón. 2007. Behaviour of biodegradable films used for mulching in melon cultivation. Acta Hort. 747:125-130, https://doi.org/ 10.17660/ActaHortic.2007.747.13.

McGeehan, S.L. and D.V. Naylor. 1988. Automated instrumental analysis of carbon and nitrogen in plant and soil samples. Commun. Soil Sci. Plant Anal. 19:493-505, https://doi.org/10.1080/ 00103628809367953.

Mehlich, A. 1978. New extractant for soil test evaluation of phosphorus, potassium, magnesium, calcium, sodium, manganese, and zinc. Commun. Soil Sci. Plant Anal. 9:477-492, https://doi.org/10.1080/00 103627809366824.

Miles, C., L. DeVetter, S. Ghimire, and D. Hayes. 2017. Suitability of biodegradable plastic mulches for organic and sustainable agricultural production systems. HortScience 52:10-15, https://doi.org/ 10.21273/HORTSCI1 1249-16.

Moreno, M. and A. Moreno. 2008. Effect of different biodegradable and polyethylene mulches on soil properties and production in a tomato crop. Scientia Hort. 116:256-263, https://doi.org/10.1016/ j.scienta.2008.01.007.

Othman, Y. and D. Leskovar. 2020. Farming system and sources of organic matter: Influence on soil health, yield, and head quality of globe artichoke. Acta Hort. 1284:93-100, https://doi.org/ 10.17660/ActaHortic.2020.1284.12.

Othman, Y. and D. Leskovar. 2018. Organic soil amendments influence soil health, yield, and phytochemicals of globe artichoke heads. Biol. Agr. Hort. 34:258-267, https://doi.org/10.1080/ 01448765.2018 .1463292 .

ReportLinker. 2020. Global mulch films industry. 2 Sept. 2021. <https://www. reportlinker.com/p05799188/?utm_source= GNW>.

Serrano-Ruíz, H., J. Eras, L. Martín-Closas, and A. Pelacho. 2020. Compounds released from unused biodegradable mulch materials after contact with water. Polym. Degrad. Stabil. 178:109202, https://doi.org/10.1016/ j.polymdegradstab.2020.109202.

Serrano-Ruiz, H., L. Martin-Closas, and A. Pelacho. 2021. Biodegradable plastic mulches: Impact on the agricultural biotic environment. Sci. Total Environ. 750:141228, https://doi.org/ 10.1016/j.scitotenv.2020.141228.

Sintim, H., S. Bandopadhyay, M. English, A. Bary, J. González, J. DeBruyn, S. Schaeffer, C. Miles, and M. Flury. 2021. Four years of continuous use of soil-biodegradable plastic mulch: Impact on soil and groundwater quality. Geoderma 381:114665, https://doi.org/10.1016/ j.geoderma.2020.114665.

Tahat, M., K. Alananbeh, Y. Othman, and D. Leskovar. 2020. Soil health and sustainable agriculture. Sustainability 12:4859, https://doi.org/10.3390/sul2124859.

Tofanelli, M. and S. Wortman. 2020. Benchmarking the agronomic performance of biodegradable mulches against polyethylene mulch film: A meta-analysis. Agronomy (Basel) 10:1618, https://doi. org/10.3390/agronomyl0101618.

Van Veen, J. and E. Paul. 1979. Conversion of biovolume measurements of soil organisms, grown under various moisture tensions, to biomass and their nutrient content. Appl. Environ. Microbiol. 37:686-692, https://doi.org/ 10.1128/aem.37.4.686-692.1979.

Vetrano, F., S. Fascella, G. Iapichino, G. Incalcaterra, P. Girgenti, P. Sutera, and G. Buscemi. 2009. Response of melon genotypes to polyethylene and biodegradable starch-based mulching films used for fruit production in the western coast of sicily. Acta Hort. 807:109-114, https://doi.org/10.17660/ ActaHortic.2009.807.12.

Wortman, S., I. Kadoma, and M. Crandall. 2016. Biodegradable plastic and fabric mulch performance in field and high tunnel cucumber production. HortTechnology 26:148-155, https://doi.org/ 10.21273/HORTTECH.26.2.148.

Zhang, H., L. DeVetter, E. Scheenstra, and C. Miles. 2020. Weed pressure, yield, and adhesion of soil-biodegradable mulches with pie pumpkin (Cucurbita pepo). HortScience 55:1014-1021, https://doi.org/ 10.21273/HORTSCI15017-20. 